\title{
Parapagus dicephalus conjoined twins and evaluation of ischiopagus tetrapus conjoined twins in Indonesia: a case report
}

\author{
Rochadi* \\ Department of Pediatric Surgery, Faculty of Medicine/Dr. Sardjito General Hospital, \\ Universitas Gadjah Mada, Yogyakarta
}

\begin{abstract}
Conjoined twins are rare occurrences in medical practice. In this study, two cases of conjoined twins, parapagus dicephalus and ischiopagus tetrapus are reported in Dr. Sardjito General Hospital, Yogyakarta, Indonesia. The first case i.e. five-day-old male parapagus dicephalus conjoined twins referred to the hospital. The twins have two heads, two arms and two legs. X-ray examination reveals two vertebrae collumn, single heart, and single pelvis. Moreover ultrasonography examination reveals conjoining of liver and echocardiography examinatin reveals single atrium. The twins were diagnosed as parapagus dicephalus. As a result of their fusion, operative care had been considered to be unacceptable. After several weeks in neonatal intensive care, they died. The second case i.e. two-day-old female conjoined twins with conjoining at ischium region referred to the hospital. Ultrasonography and abdominal examination reveal conjoining at intestinum, buttock and ischium. The twins was diagnsed as ischiopagus tetrapus. They were successfully separated at 6 months of age. They are alive and well so far for more than 7 years. In conclusion, the prognosis of conjoined twins is related to the type, extent of union and organ abnormalities. The successful separation of conjoined twins might be determined by good planning and staff enthusiasm and dedication.
\end{abstract}

\section{ABSTRAK}

Bayi kembar siam adalah kejadian langkan di dunia kedokteran. Dalam makalah ini dilaporkan dua kasus bayi kembar siam yaitu parapagus dicephalus dan ischiopagus tetrapus di Rumah Sakit Umum Dr. Sardjito, Yogyakarta, Indonesia. Kasus I adalah bayi kembar siam laki-laki berumur lima hari dikirim ke rumah sakit. Bayi kembar siam tersebut mempunyai dua kepala, dua lengan dan dua kaki. Hasil pemeriksaan rontgen didapatkan dua kolumna vertebralis, satu jantung dan satu panggul. Selanjutnya hasil pemeriksaan ultrasonografi menunjukkan penyatuan liver sedangkan hasil pemeriksaan ekokardiografi menunjukkan satu atrium. Penderita didiagnosis sebagai parapagus dicephalus. Akibat penyatuan organ ini tindakan operasi tidak memungkinkan dilakukan. Setelah beberapa minggu dalam perawatan intensif, bayi kembar siam tersebut meninggal. Kasus II adalah bayi kembar siam perempuan berumur dua hari dengan penyatuan pada pantat dikirim ke rumah sakit. Hasil pemeriksaan ultrasonografi dan scanning abdomen menunjukkan adanya penyatuan pada usus, pantat, dan panggul. Penderita didiagnosis sebagai ischiopagus tetrapus. Operasi pemisahan berhasil dilakukan dengan baik pada umur 6 bulan. Mereka hidup sehat dan baik sejauh ini setelah tujuh tahun sejak dipisahkan. Dapat disimpulkan, prognosis kembar siam tergantung jenis dan tingkat penyatuan serta kelainan organ bayi. Keberhasilan pemisahan bayi kembar siam ditentukan oleh perencanaan operasi yang baik, dedikasi dan semangat tenaga medik dalam menjalankan tugasnya.

Key words: conjoining twins - parapagus dicephalus - ischiopagus tetrapus - operation - prognosis

\footnotetext{
* corresponding author: fkugmbedahanak@yahoo.co.id
} 


\section{INTRODUCTION}

Conjoined twins are identical same-sex twins that develop from a single fertilized ovum. The incidence of conjoined twins is approximately $1: 50,000-200,000$ live births. Females are most commonly affected, with a ratio of female/male of $4: 1 .^{1}$ The earliest successful separation of conjoined twins was performed at Switzerland in 1689. The term Siamese twins was popularized when Eng and Chang, born in Siam in $1811 .^{2}$

Conjoined twins consist of eight subtypes according to a dorsal or ventral conjoin: omphalopagus, thoracopagus, cephalopagus, ischiopagus, parapagus, craniopagus, rachipagus and pyopagus. Thoracopagus is the commonest one (40\%) followed by omphalopagus $(32 \%)$, pygopagus $(19 \%)$, ischiopagus $(6 \%)$, and craniopagus $(2 \%))^{3-5}$

Parapagus is a rare form of conjoined twins, in which the twins have a side-by-side connection with a shared pelvis and variable cephalad sharing. They represent less than $0.5 \%$ of all cases of conjoined twins. ${ }^{5-7}$ There are case reports presenting dicephalic conjoined twins, either tetrabrachius or dibrachius. ${ }^{6}$

Ischiopagus is a type of conjoined twins which share a conjoined pelvis and are more commonly joined end-to-end and less frequently face-to-face with a conjoined abdomen. ${ }^{7}$ Ischiopagus twins can be classified by the number of legs present as tetrapus (four legs) or tripus (three). ${ }^{2}$

The birth of conjoined twins raises serious ethycal consideration. The development of surgical separation techniques and anticipated long term survival of one or both twins places parents and physicians in a unique and difficult situation from the moment of delivery. Transfer of conjoined twins immediately after delivery to institution with special interest in separation procedures is usually wise. Initially medicine had little to offer conjoined twins even as recently as the last century, conjoined twins such as Chang and Eng Bunker were not concidered separable by most physicians and surgeon. Now complex conjoined twins can be considered for separation and have acceptable long-term outcomes. Prenatal evaluation with both ultrasound and fetal echocardiography permits thoughtful consultation with the parents regarding the probable outcome and potential problems. $^{3-5}$

So far, there have been no such reports from the Indonesian population. In this study, two cases of conjoining twins, parapagus dicephalus and ischiopagus tetrapus, in Dr. Sardjito General Hospital, Yogyakarta, Indonesia were reported.

\section{CASE REPORT}

\section{Case 1. Parapagus dicephalus}

Five-day-old male parapagus dicephalus conjoined twins referred to Dr. Sardjito General Hospital. They were born from a healthy 27year-old mother by Caesarean section in June 1 st, 2013 in a rural hospital. These girls weighed 4,200 g (FIGURE 1). The twins had two heads, two arms and two legs.

Plain photo showed two separate vertebral columns, one shared heart, one liver, two lungs, and a partially shared gastrointestinal tract with two separate stomachs (FIGURE 2). As a result of their fusion, operative care had been considered to be unacceptable. After several weeks in neonatal intensive care unit, they died. 


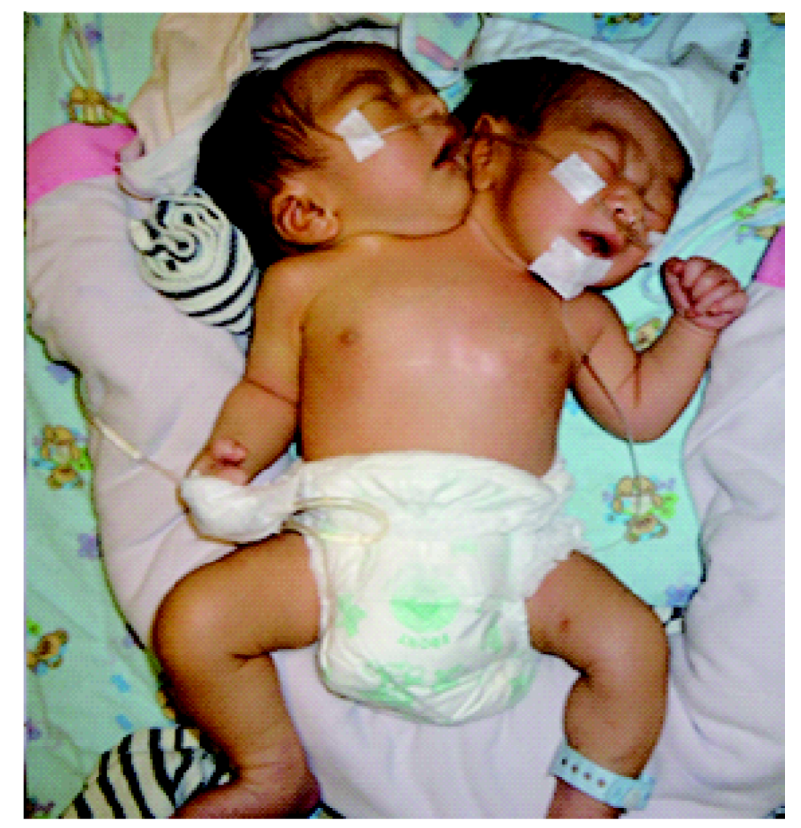

FIGURE 1. The parapagus conjoined twins

\section{Case 2. Ischiopagus tetrapus}

Two-day-old female ischiopagus tetrapus conjoined twins referred to Dr. Sardjito General Hospital. They were born from a healthy 28year-old mother by normal delivery in January 2006 in rural hospital with their weight of 5,454 grams.

They shared a conjoined pelvis with four arms and four legs. The umbilical cord was single (FIGURE 3). All organ system were evaluated by

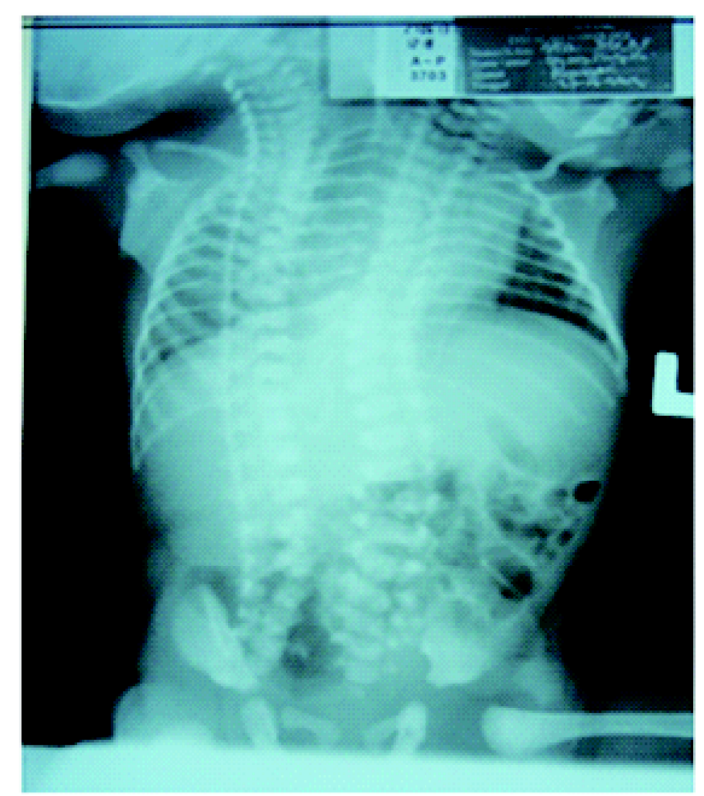

FIGURE 2. X-ray of the conjoined twins.

X-ray, renogram, ureterocystogram, barium enema and CT scan. The bony pelvis formed a ring and joined with the normal lower limbs. The upper and lower gastrointestinal studies showed normal and separate stomach, small intestines, single cecum, single ascending colon and single appendix. The small intestines joined in the terminal ileum as a single unit. Each baby had two kidneys with two ureters and one bladder.
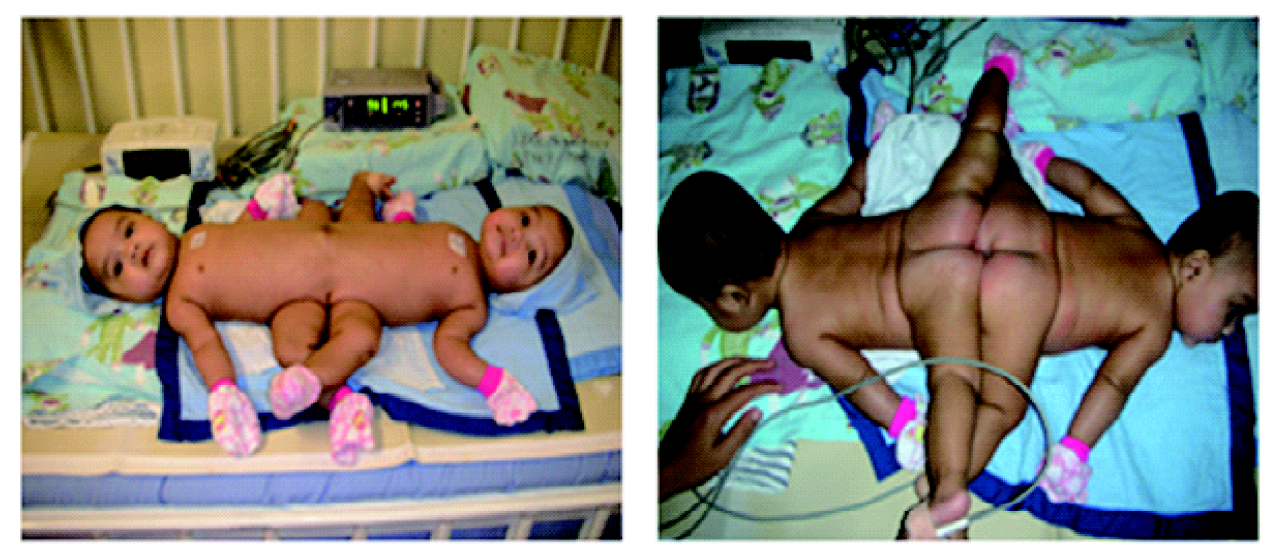

FIGURE 3. a. Ventral view of ischiopagus tetrapus twins; b. Posterior view of ischiopagus tetrapus twins. 
Separation was performed at the age of 6 months at a body weight of $8,000 \mathrm{~g}$. The peritoneum was opened transversely. Each infant had a normal stomach, duodenum, liver, gall bladder, pancreas, spleen and small intestines. The small intestines joined in the terminal ileum as a single unit approximately $15 \mathrm{~cm}$ from the ileo-caecal junction. They had one ascending colon, single transverse colon, two sigmoid and two rectums. The two small intestines were transected at the junction where they joined in the terminal ileum as a single unit.

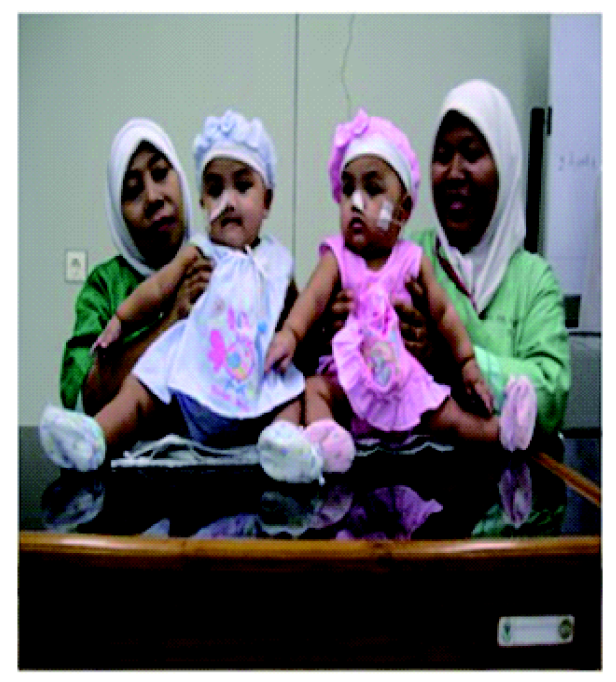

FIGURE 4. The twins in one year old

\section{DISCUSSION}

In the present study, two cases of conjoining twins, parapagus dicephalus and ischiopagus tetrapus, in Dr. Sardjito General Hospital, Yogyakarta, Indonesia were reported. The parapagus dicephalus died after several weeks in neonatal intensive care unit, while the ischiopagus tetrapus conjoined twins have been successfully separated at 6 months old, and so far have normal development for more than 7 years.

Interestingly, conjoined twins showed a significant female predominance especially of the thoracopagus type, but a significant male
The transverse colon was then divided and an ileotransversostomy anastomosis was performed. The babies did well on the postoperative period. At 3 days post operative, however, one of the baby developed peritonitis due to intestinal anastomosis leakage which was successfully treated by colostomy and reanastomosis.

They are being followed so far for more than 7 years, with normal development (FIGURE 4 and 5).

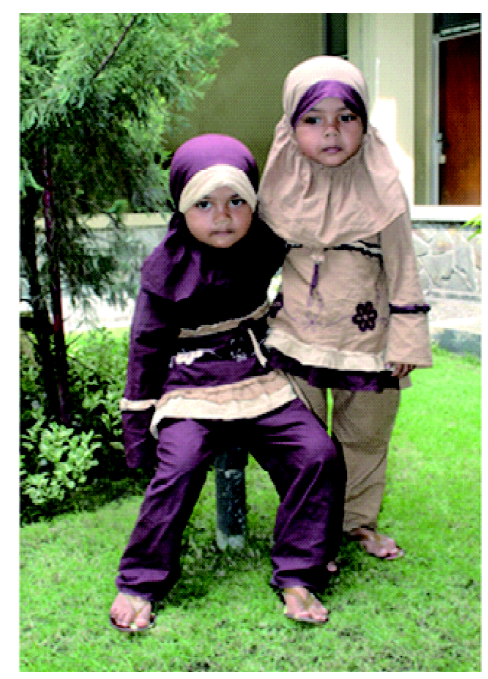

FIGURE 4. Twins 7 years post-separation

predominance for parapagus type ${ }^{8,9}$ Our first case is consistent with these studies.

Previous study reported that some of parapagus dicephalus are reported stillborn while others died shortly after birth. ${ }^{9}$ Parapagus dicephalus conjoined twins may have a long life which depends on the degree of conjunction and abnormality of the hearts. ${ }^{9}$ A few parapagus dicephalus parapagus conjoined twins remained alive as unseparated. Our case belongs to the one died shortly after birth. Basaran et al. ${ }^{9}$ suggested that early prenatal diagnosis is very important to escape this conjoined twins type and the unimaginable stress for the family. 
The first successful separation of ischiopagus tetrapus conjoined twins was reported in 1966, followed by others studies. ${ }^{10}$ The best time to separate conjoined twins depends on anatomic and physiologic factors, and the recommendation age is between 2 to 12 months, except under emergent conditions. ${ }^{10}$ Our second case is successfully separated at 6 months old and survived with normal development. It is highly possible to successfully separate conjoined twins in developing countries such as Indonesia, if the operation was being prepared and performed by dedicated and enthusiastic staff.

\section{CONCLUSION}

In conclusion, the prognosis of conjoined twins is related to the type, extent of union and organ abnormalities. The successful separation of conjoined twins might be determined by good planning and staff enthusiasm and dedication.

\section{ACKNOWLEGEMENTS}

The authors would like to thank our colleagues from Dr. Sardjito General Hospital for the valuable assistances during separation performed.

\section{REFERENCES}

1. Bondeson J. Dicephalus conjoined twins: a historical review with emphasis on viability. J Pediatr Surg 2001; 36: 1435-44.
2. Saguil E, Almonte J, Baltazar W, Acosta A, Caballes A, Catangui A, et al. Conjoined twins in the Philippines: experience of a single institution. Pediatr Surg Int 2009; 25(9):775-80. Doi: 10.1007/s00383-009-2426-7.

3. Holcomb GW, O’Neill JA. Conjoined twins. In: Ashcraft K, Holder T, editors. Pediatric Surgery. $2^{\text {nd }}$ ed. Philadelphia: WB Saunders, 1993: 948-55.

4. Schnaufer UG. Conjoined twins. In: Raffensperger JG, editor. Swenson's Pediatric Surgery. $5^{\text {th }}$ ed. Connecticut: Appleton \& Lange, 1990:969-77.

5. Spencer R. Conjoined twins. In: Holcomb III, GW, Murphy JP, Ostlie DJ, editors. Ashcraft's Pediatric Surgery. $3^{\text {rd }}$ ed. Philadelphia: WB Saunders, 2005:1040-53.

6. Spitz L. Conjoined twins. Prenat Diagn, 2005; 25:814-9.

7. Winkler N, Kennedy A, Byrne J, Woodward P. The imaging spectrum of conjoined twins. Ultrasound Q, 2008; 24: 249-55.

8. Mutchinick OM, Luna-Munoz L, Amar E, Bakker MK, Clementi M, Cocchi G, et al. Conjoined twins: a worldwide collaborative epidemiological study of the International Clearinghouse for Birth Defects Surveillance and Research. Am J Med Genet C Semin Med Genet 2011; 157: 274-87.

9. $\mathrm{Ba}^{\mathrm{o}}$ aran S, Güzel R, Keskin E, Sarpel T. Parapagus (dicephalus, tetrabrachius, dipus) conjoined twins and their rehabilitation. Turk J Pediatr 2013; 55: 99-103.

10. Freeman NV, Fahr J, Al-Khusaiby S. Separation of ischiopagus tetrapus conjoined twins in the Sultanate of Oman. Pediatr Surg Int 1997; 12: 256260 . 